\title{
Co-feeding transmission in Lyme disease pathogens
}

\author{
MAARTEN J. VOORDOUW* \\ Institute of Biology, Laboratory of Ecology and Evolution of Parasites, University of Neuchâtel, Emile Argand 11, \\ 2000 Neuchâtel, Switzerland
}

(Received 8 Fuly 2014; revised 8 August 2014; accepted 18 August 2014; first published online 8 October 2014)

SUMMARY

This review examines the phenomenon of co-feeding transmission in tick-borne pathogens. This mode of transmission is critical for the epidemiology of several tick-borne viruses but its importance for Borrelia burgdorferi sensu lato, the causative agents of Lyme borreliosis, is still controversial. The molecular mechanisms and ecological factors that facilitate co-feeding transmission are therefore examined with particular emphasis on Borrelia pathogens. Comparison of climate, tick ecology and experimental infection work suggests that co-feeding transmission is more important in European than North American systems of Lyme borreliosis, which potentially explains why this topic has gained more traction in the former continent than the latter. While new theory shows that co-feeding transmission makes a modest contribution to Borrelia fitness, recent experimental work has revealed new ecological contexts where natural selection might favour co-feeding transmission. In particular, co-feeding transmission might confer a fitness advantage in the Darwinian competition among strains in mixed infections. Future studies should investigate the ecological conditions that favour the evolution of this fascinating mode of transmission in tick-borne pathogens.

Key words: Borrelia burgdorferi, co-feeding transmission, epidemiology, saliva-assisted transmission, tick-borne pathogens.

\section{INTRODUCTION}

Co-feeding transmission is a mode of transmission that has been reported for a wide diversity of vectorborne pathogens (Jones et al. 1987; Randolph et al. 1996; Mead et al. 2000; Higgs et al. 2005). With respect to tick-borne pathogens, this mode of transmission was first discovered for tick-borne viruses such as Thogoto virus (Jones et al. 1987) and tickborne encephalitis virus (TBEV) (Alekseev and Chunikhin, 1990; Labuda et al. 1993a, b) and was subsequently described in Borrelia burgdorferi sensu lato $(s . l$.), the complex of spirochaete bacteria that causes Lyme borreliosis (Gern and Rais, 1996; Randolph et al. 1996). While the importance of co-feeding transmission for TBEV epidemiology is now widely accepted (Randolph, 2011), the role of co-feeding transmission in the epidemiology of B. burgdorferi s. l. is more controversial (Randolph et al. 1996; Richter et al. 2002, 2003; Randolph and Gern, 2003). The controversy of whether co-feeding transmission is ecologically relevant to Borrelia pathogens has recently been invigorated with a number of theoretical and experimental studies.

* Corresponding author. Institute of Biology, Laboratory of Ecology and Evolution of Parasites, University of Neuchâtel, Emile Argand 11, 2000 Neuchâtel, Switzerland. E-mail: maarten.voordouw@unine.ch
Theoretical work on the basic reproductive number of tick-borne pathogens suggests that co-feeding makes a modest contribution to Borrelia fitness but that spirochaetes can invade tick populations without this mode of transmission (Hartemink et al. 2008; Harrison et al. 2011; Harrison and Bennett, 2012. In contrast, the fieldwork suggests that co-feeding transmission may enhance Borrelia fitness in vertebrate hosts that are otherwise refractory to systemic infection by spirochaetes (Morán Cadenas et al. 2007; Kiffner et al. 2011; Kjelland et al. 2011). Experimental infection work has found evidence for genetic variation in co-feeding transmission among strains of Borrelia suggesting that this trait can evolve in response to natural selection (Tonetti and Gern, 2011). Thus co-feeding transmission could influence the Darwinian competition among strains for transmission success and by extension, the genetic community of Borrelia strains in the populations of the tick vector and the reservoir host (Pérez et al. 2011). In addition, co-feeding transmission may facilitate contact between Borrelia genospecies that are adapted to different vertebrate host species (Kurtenbach et al. 2001; Pichon et al. 2003; Herrmann et al. 2013). Thus co-feeding transmission may allow genetic exchange between Borrelia pathogens that are otherwise genetically isolated. In the present review, I discuss the ecological significance of co-feeding transmission and the underlying molecular mechanisms with

Parasitology (2015), 142, 290-302. C Cambridge University Press 2014. This is an Open Access article, distributed under the terms of the Creative Commons Attribution licence (http://creativecommons.org/licenses/by/3.0/), which permits unrestricted re-use, distribution, and reproduction in any medium, provided the original work is properly cited. 

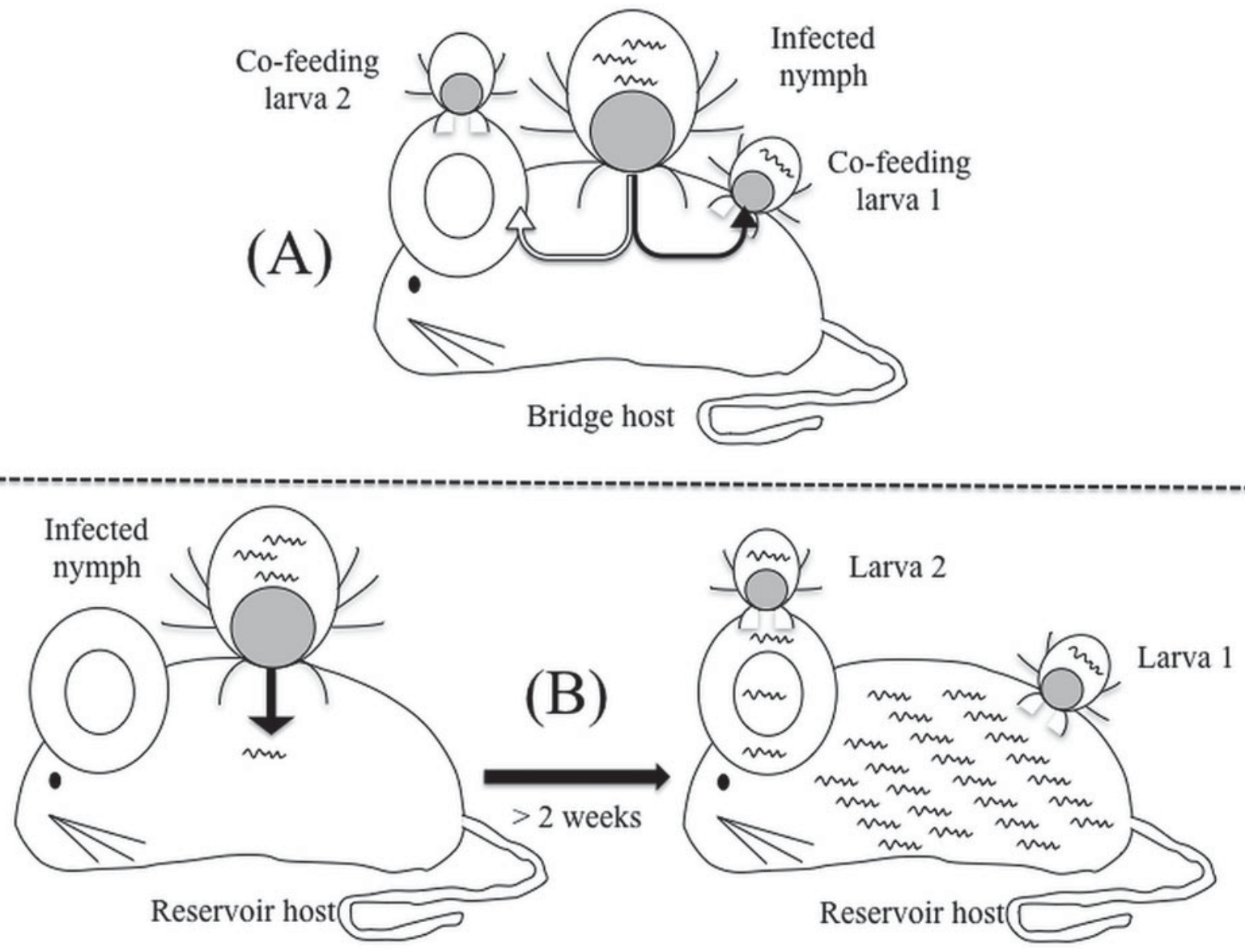

Fig. 1. The diagram shows (A) co-feeding (nymph-to-larva) transmission and (B) systemic (host-to-larva) transmission of Borrelia spirochaetes in a rodent reservoir host. Co-feeding transmission can occur when ticks feed in close spatial and temporal proximity on the same host. Larva 2 does not acquire spirochaetes via co-feeding transmission because it is too far away from the infected nymph. Systemic transmission occurs once the spirochaetes have had enough time to disseminate to all the relevant tissues of the reservoir host, which usually takes about 2 weeks. Under systemic transmission, larvae can acquire spirochaetes by attaching anywhere on the infected mouse.

particular emphasis on its importance to Borrelia pathogens.

\section{CO-FEEDING TRANSMISSION AND TICK-BORNE PATHOGENS}

\section{Definition of co-feeding transmission of tick-borne pathogens}

Co-feeding transmission is a mode of transmission of vector-borne pathogens that is distinct from systemic transmission (Fig. 1). Co-feeding transmission occurs when infected and uninfected vectors feed in spatiotemporal proximity to each other on the same reservoir host (Randolph et al. 1996; Randolph, 2011). This mode of transmission may be particularly significant for tick-borne pathogens because ticks, unlike other arthropod vectors, often attach to the host for several days to obtain a meal (Randolph, 1998; Nuttall, 1999). Co-feeding transmission often depends on an ephemeral, localized infection in the skin and is distinct from systemic transmission where the vector-borne pathogen disperses from the initial bite site and establishes a widespread (systemic) infection in the host organism (Fig. 1). In co-feeding transmission, the host acts as a transient bridge that brings infected and uninfected ticks together in the same time and place to facilitate pathogen exchange (Randolph, 2011). By contrast, in systemic transmission, the infected host acts as a reservoir from which vectors can acquire the pathogen for weeks or even months after the host became infected. In systemic transmission, there is often a latency period where the pathogen is replicating inside the host but the latter is not yet infectious to new vectors. By contrast, the latency period of co-feeding transmission is much shorter and is virtually instantaneous for some tick-borne viruses.

\section{Tick-borne pathogens capable of co-feeding transmission}

Co-feeding transmission was first demonstrated in two tick-borne viruses: Thogoto virus (Jones et al. 1987) and TBEV (Alekseev and Chunikhin, 1990; Labuda et al. 1993a, b). These two arboviruses were both transmitted between co-feeding ticks without inducing detectable viral titres (viraemia) in 
the blood of their rodent hosts (Jones et al. 1987; Labuda et al. 1993a, b). Labuda et al. (1997) demonstrated that co-feeding transmission of TBEV can even occur on immunized rodents where sterilizing antibodies prevent the development of a viraemic infection. By knocking out systemic infection, this immunization experiment provided an elegant demonstration that co-feeding transmission is a distinct mode of pathogen transfer that can operate independently from systemic transmission (Labuda et al. 1997). Following its discovery in tick-borne viruses, co-feeding transmission was subsequently demonstrated in two groups of tick-borne bacteria: intracellular gram-negative bacteria belonging to the genus Anaplasma (formerly Ehrlichia) (Levin and Fish, 2000) and spirochaete bacteria belonging to the $B$. burgdorferi s. $l$. genospecies complex (Gern and Rais, 1996; Patrican, 1997; Sato and Nakao, 1997; Piesman and Happ, 2001; Richter et al. 2002; Hu et al. 2003). Interestingly, the Anaplasma genus exhibits species-specific differences in co-feeding transmission as the phenomenon was demonstrated in Anaplasma phagocytophilum (Levin and Fish, 2000) but not in the closely related Anaplasma marginale (Kocan and de la Fuente, 2003). In summary, cofeeding transmission has been demonstrated in a variety of tick-borne pathogens including viruses and bacteria.

\section{Co-feeding transmission in B. burgdorferi s. 1.}

The B. burgdorferi s. l. genospecies complex contains a number of pathogens that cause Lyme borreliosis, the most common tick-borne disease in the Northern Hemisphere. Co-feeding transmission has been demonstrated for the three B. burgdorferi s. l. genospecies that are most commonly associated with human Lyme borreliosis: B. burgdorferi sensu stricto (s.s.) (Gern and Rais, 1996; Patrican, 1997; Piesman and Happ, 2001; Hu et al. 2003), Borrelia afzelii (Richter et al. 2002; Hu et al. 2003), and Borrelia garinii (Sato and Nakao, 1997; Hu et al. 2003), as well as Borrelia valaisiana (Hu et al. 2003). One reason for the controversial role of co-feeding transmission in Lyme disease is because systemic transmission of Borrelia spirochaetes from the reservoir host to the tick vector is highly efficient. For example, in the North American system of B. burgdorferi s. s. and the tick vector Ixodes scapularis, the systemic transmission rate from competent reservoir hosts such as the white-footed mouse, Peromyscus leucopus, can reach 90\% (Donahue et al. 1987). By contrast, cofeeding transmission in this system was 20 -fold lower $(5 \%)$ and only occurred under very unrealistic tick infestation conditions (mice were infested with $\sim 28$ infected nymphs and 200 larvae) (Piesman and Happ, 2001). Co-feeding transmission of B. burgdorferi s. s. was higher in two other studies where the authors used either an unnatural gerbil reservoir host
(18-88\%) (Patrican, 1997) or European strains of B. burgdorferi s. s. in combination with Ixodes ricinus ticks (32.5-60.9\%) (Gern and Rais, 1996). In the European system of $B$. afzelii and the tick vector I. ricinus, co-feeding transmission ranged from $1 \cdot 6$ to $55 \cdot 3 \%$ under realistic tick infestation conditions (mice were infested with one infected nymph) (Richter et al. 2002). A study on field-collected I. ricinus ticks that were mostly infected with $B$. afzelii found that $95 \%(105 / 111)$ of all laboratory mice produced at least one co-infected tick ( $\mathrm{Hu}$ et al. 2003) but unfortunately, the mouse-specific co-feeding transmission rates were not reported ( $\mathrm{Hu}$ et al. 2003). A study on B. garinii and Ixodes persulcatus ticks found that the co-feeding transmission rates ranged from $6 \cdot 0$ to $29 \cdot 0 \%$ (Sato and Nakao, 1997). While experimental differences in Borrelia genospecies, tick vector species and reservoir hosts make it difficult to generalize, co-feeding transmission appears to be more efficient in the European system of $B$. afzelii and $I$. ricinus than the North American system of B. burgdorferi s. s. and I. scapularis.

The viability of spirochaetes acquired via cofeeding transmission remains an open question. Many studies that measure co-feeding transmission use detection methods such as fluorescent antibody tests or PCR, which cannot establish whether the B. burgdorferi s. . spirochaetes in the co-feeding ticks are actually alive (Gern and Rais, 1996; Patrican, 1997; Sato and Nakao, 1997; Richter et al. 2002). Evidence that co-feeding transmits viable $B$. burgdorferi s. l. comes from two studies that cultured live spirochaetes from co-feeding ticks (Piesman and Happ, 2001; Hu et al. 2003). However, in both of these studies, the spirochaetes were cultured in BarbourStoenner-Kelly (BSK) medium within 1 week of the co-feeding transmission event. In contrast, under natural conditions, Borrelia spirochaetes typically spend many months inside the nymphal tick before infecting a new vertebrate reservoir host. Thus the long-term survival prospects of co-feeding acquired spirochaetes in the tick vector remain unknown. Similarly, whether spirochaetes acquired via cofeeding transmission are infectious to vertebrate reservoir hosts also remains unknown.

\section{ECOLOGY OF CO-FEEDING TRANSMISSION}

Larval and nymphal ticks maintain Lyme borreliosis in nature because these two immature tick stages feed on the same suite of reservoir hosts. Larvae (being the younger stage) are an order of magnitude more common than nymphs into which they develop following the larval blood meal. The generational transfer of Borrelia spirochaetes from a few infected nymphs to many uninfected larvae (via the host upon which they are feeding) is the critical life history event that defines the reproductive number $\left(R_{0}\right)$ and the epidemiology of Lyme disease (Randolph, 1998; 
Tsao, 2009). Transstadial maintenance of the infection, where infected, blood-engorged larvae maintain the infection during the moult and develop into the next generation of Borrelia-infected nymphs, is another essential feature of the spirochaete life cycle. Naive recipient larval ticks can acquire spirochaetes from feeding on an infected reservoir host (host-to-larva systemic transmission) or from feeding next to an infected donor nymph on a bridge host (nymph-to-larva co-feeding transmission). Nymphto-nymph co-feeding transmission is possible (Patrican, 1997) but is much less common than nymph-to-larva co-feeding transmission. A field study on wild rodents in Slovakia found 12,032 attached larvae and 400 attached nymphs (Randolph et al. 1999). Thus in this particular rodent community, nymph-to-larva co-feeding transmission occurred 30 times more often than nymph-to-nymph transmission and the latter is therefore largely irrelevant to the fitness of tick-borne pathogens. Transovarial transmission has enormous potential to enhance spirochaete fitness because one infected female can produce many infected offsprings. However, two recent studies suggest that previous reports of transovarial transmission in B. burgdorferi s. l. were confounded by co-infection with Borrelia miyamotoi, a recently discovered species that belongs to the relapsing fever-group (Richter et al. 2012; Rollend et al. 2013). These new developments therefore suggest that transovarial transmission does not occur in B. burgdorferi s. l. (Richter et al. 2012; Rollend et al. 2013). The two key fitness components of B. burgdorferi s. $l$. pathogens are therefore the number of infected larvae produced via co-feeding transmission and the number of infected larvae produced via systemic transmission.

\section{Synchronous questing activity of immature ticks}

Successful co-feeding transmission requires that larval and nymphal ticks feed at the same time and on the same host. Co-feeding transmission therefore has two necessary ecological conditions: synchrony of larval and nymphal host-searching (questing) activity and the co-occurrence of larvae and nymphs on the same host (Randolph et al. 1996, 1999). Differences in climate between North America and Europe produce contrasting tick activity patterns (phenologies) (Kurtenbach et al. 2006) with important consequences for co-feeding transmission. In North America, immature I. scapularis ticks exhibit asynchronous phenologies; peak nymphal and larval questing activities occur at different times of the year (early and late summer, respectively). By contrast, in Europe, immature I. ricinus ticks are active at the same time from spring to autumn (Craine et al. 1995; Kurtenbach et al. 2006; Burri et al. 2011). The potential for spirochaete co-feeding transmission is therefore probably much greater in Europe than in
North America. A recent study in North America showed that climate-induced differences in the seasonal synchrony of tick questing activity can influence the community of circulating Borrelia strains (Gatewood et al. 2009). In the Northeast, a large temporal gap between peak nymphal and peak larval questing activity (i.e. high seasonal asynchrony) favours strains of B. burgdorferi s. s. that are longlived inside the reservoir host (Gatewood et al. 2009). These long-lived strains are also more invasive in humans suggesting that interactions between climate, tick phenology and strain phenotype can have important consequences for the epidemiology of Lyme borreliosis.

Interestingly, climate change is predicted to have different consequences for co-feeding transmission on these two continents. In North America, climate change is expected to speed up the onset of larval activity patterns thereby increasing the scope for cofeeding transmission (Ogden et al. 2007). In Europe, by contrast, climate change is predicted to disrupt transmission cycles of tick-borne pathogens that are highly dependent on coincident feeding and cofeeding transmission (Randolph and Rogers, 2000; Randolph and Sumilo, 2007). For example, depending on the climate change scenario, TBEV will be largely eliminated from central Europe by 2050 (Randolph and Rogers, 2000; Randolph and Sumilo, 2007).

\section{Co-occurrence and aggregation of immature ticks on the same host}

Co-occurrence of infected nymphs and susceptible larvae on the same host is another critical ecological condition for co-feeding transmission. Ticks are often highly aggregated on just a few hosts and follow the '20/80 Rule' (Woolhouse et al. 1997) where $20 \%$ of the reservoir hosts feed about $80 \%$ of the immature ticks (Randolph et al. 1999; Perkins et al. 2003; Devevey and Brisson, 2012). In general, those host individuals that feed the greatest number of nymphs also tend to feed and infect the greatest number of larvae (Craine et al. 1995; Randolph et al. 1999; Brunner and Ostfeld, 2008). For example, a field study of wild rodents in Slovakia found that $26 \%$ of the most heavily infested individuals fed up to $75 \%$ of the nymphs and $86 \%$ of the larvae (Randolph et al. 1999). A field survey of yellow-necked mouse, Apodemus flavicollis, found that $20 \%$ of the mice (mostly adult males) fed $83 \%$ of the larvae and hosted $72 \%$ of the co-feeding events (Perkins et al. 2003). Similarly, a field survey on the wood mouse, Apodemus sylvaticus, found that $20 \%$ of the mice hosted all the nymphs and $72 \%$ of the larvae (Harrison et al. 2011). Calculation of the reproductive number $\left(R_{0}\right)$ for tick-borne pathogens such as TBEV suggests that these co-occurrence patterns of immature ticks on the same host increase pathogen 
fitness by a factor of three in comparison to the null hypothesis of independent larval and nymphal distributions (Randolph et al. 1999). Thus coincident feeding of immature ticks is critical for maintaining and amplifying co-feeding transmission.

There are a variety of reasons why ticks are aggregated on a subset of their hosts. Questing larvae are often highly aggregated in space because they hatch from a single egg batch and have limited dispersal (Steele and Randolph, 1985; Daniels and Fish, 1990). Male rodents tend to have higher tick burdens than female rodents because they are bigger and have larger home ranges (Randolph, 1975; Perkins et al. 2003). Another reason why male rodents are believed to be susceptible to high tick infestations is because their immune system is suppressed by testosterone (Hughes and Randolph, 2001). Estimates of tick burden and coincident aggregation are critical for parameterizing models that estimate the contributions of co-feeding and systemic transmission to the fitness of tick-borne pathogens (Harrison and Bennett, 2012).

\section{Mechanics of co-feeding transmission - time and distance}

The efficiency of co-feeding transmission of B. burgdorferi $s$. $l$. depends on two important factors: the time between larval and nymphal fixation and the distance between the larval and nymphal attachment sites. To measure co-feeding transmission, workers typically place xenodiagnostic larvae on the host at the same time (Patrican, 1997; Sato and Nakao, 1997; Piesman and Happ, 2001) or a few days (2-5 days) after attachment of the Borrelia-infected nymphs (Gern and Rais, 1996; Richter et al. 2002; Hu et al. 2003). In the B. afzelii-I. ricinus system, co-feeding transmission increased from $0 \cdot 0$ to $55 \cdot 3 \%$ as the duration of nymphal attachment before larval attachment increased from 0 to 3 days (Richter et al. 2002). Cofeeding transmission on a bridge host can take place even when the nymphs and larvae are not attached at the same time. In B. burgdorferi s. $s$. and the tick vector $I$. ricinus, co-feeding transmission from the site of infected nymphal attachment (the back of the mouse) occurred for 14 days, even after infected nymphs had detached, while systemic transmission from a distant site (the head) was not observed until 29 days following nymphal attachment (Gern and Rais, 1996). Thus systemic transmission is separated in time from co-feeding transmission.

The distance between co-feeding ticks is another factor that influences the efficiency of co-feeding transmission. Workers often place nymphs and larvae in capsules that are fixed to the skin of the bridge host to manipulate the distance at which ticks cofeed from each other (Gern and Rais, 1996; Sato and Nakao, 1997; Hu et al. 2003). In the B. afzelii-I. ricinus system, co-feeding transmission declines from
$55 \cdot 3$ to $25 \cdot 6$ to $6 \cdot 3 \%$ as the distance between nymphs and larvae increases from 0.0 to $1 \cdot 0$ to $2 \cdot 0 \mathrm{~cm}$ (Richter et al. 2002). This spatial constraint would appear to reduce the importance of co-feeding transmission to spirochaete fitness. However, ticks do not randomly select feeding attachment sites and are often spatially clustered on the host. Most immature Ixodes ticks are found on the ears, head and neck of their rodent hosts (Randolph, 1975; Craine et al. 1995; Schmidt et al. 1999), presumably to avoid host grooming, which represents a significant source of tick mortality (Shaw et al. 2003; Keesing et al. 2009). A field survey of squirrels in England found that $95 \%$ of all immature I. ricinus ticks were found on the ears (Craine et al. 1995). Randolph suggested that $\sim 45 \%$ of feeding ticks are within $\sim 1 \mathrm{~cm}$ of each other on the rodent host, thereby greatly facilitating co-feeding transmission (Randolph, 2011). Spatial clustering of I. ricinus ticks was also observed on sheep in the northwest UK where $90 \%$ of the ticks were found on $20 \%$ of the sheep surface area (the part that was not covered by wool) (Ogden et al. 1998a). In these sheep populations, co-feeding is believed to be the predominant mode of spirochaete transmission (Ogden et al. 1997). A study on roe deer found that $54 \%$ of the total tick load was found on only $12 \%$ of the total surface area of the animals (Kiffner et al. 2011). Thus spatial clustering of $I$. ricinus larval and nymphal ticks is commonly observed in both rodents and ungulates.

In some tick species, co-occurrence on the same host and spatial clustering of ticks on the same host surfaces appear to be mediated by pheromones (Sonenshine, 2004). Spatial clustering may also facilitate cooperative feeding among ticks as demonstrated in several species of ixodid ticks (Wang et al. 1998; Rechav and Nuttall, 2000; Wang et al. 2001b). In $I$. ricinus for example, nymphs that co-fed with larvae had higher feeding success and greater engorgement weights than nymphs that did not co-feed with larvae (Ogden et al. 1998b). Cooperative feeding, by allowing vectors to pool their saliva, may enhance the immunomodulatory manipulation of the host organism. If the immunomodulatory constituents of tick saliva are costly, cooperative feeding could increase the cost-benefit ratio of resource extraction from the host relative to per capita investment in tick saliva production. Avoidance of host grooming behaviour, pheromone-induced aggregation and cooperative feeding are different mechanisms that enhance the spatial clustering of ticks on the same host. In turn, these spatial clustering mechanisms cause ticks to feed on the same patch of skin thereby enhancing cofeeding transmission of spirochaetes.

MOLECULAR MECHANISMS OF CO-FEEDING TRANSMISSION

The molecular mechanisms that facilitate co-feeding transmission are better understood for TBEV than 
for Borrelia pathogens. Co-feeding transmission of TBEV appears to be mediated by migratory leucocytes. Langerhans cells, the dendritic cells that reside in the skin, appear to be recruited to the tick-feeding site where they acquire TBEV (Labuda et al. 1996). Infected Langerhans cells are believed to transmit the virus to $\mathrm{T}$ lymphocytes in the local lymph nodes (Nuttall, 1999; Nuttall and Labuda, 2003). The infected $\mathrm{T}$ lymphocytes are then recruited to the feeding sites of uninfected ticks thereby completing the co-feeding transmission cycle of TBEV (Nuttall, 1999; Nuttall and Labuda, 2003). Perhaps migratory leucocytes play a similar role in the co-feeding transmission of intracellular tick-borne bacteria such as A. phagocytophilum (Levin and Fish, 2000). Borrelia, being an extracellular bacterium, is therefore unlikely to use migratory leucocytes for transmission between co-feeding ticks (although there is some evidence that spirochaetes can be re-cultured from phagocytes following transport to the lymphatic system (Montgomery et al. 1993)). Borrelia spirochaetes likely rely on their periplasmic flagella that allow them to migrate autonomously through the tissues of the reservoir host (Charon et al. 2012). Co-feeding transmission of Borrelia spirochaetes may also benefit from saliva-assisted transmission (SAT) (Nuttall and Labuda, 2004), as this phenomenon is known to enhance co-feeding transmission of tick-borne viruses (Labuda et al. 1993c).

\section{Saliva-assisted transmission and co-feeding transmission}

Ticks use their saliva to modulate the haemostatic, inflammatory and immune responses of the hosts and thereby optimize blood uptake (Brossard and Wikel, 2004). Tick saliva contains a wide variety of pharmacologically active agents that suppress both the innate and the acquired immune system of the vertebrate host (Nuttall, 1999; Nuttall and Labuda, 2004; Randolph, 2009). Tick saliva creates a zone of immunosuppression around the site of tick feeding that is beneficial to both the ticks and tick-borne pathogens. SAT thus refers to the phenomenon where saliva of the arthropod vector increases the transmission of vector-borne pathogens (Ribeiro, 1995). SAT and co-feeding transmissions are clearly connected; the pooled saliva of ticks feeding in close spatiotemporal proximity creates an environment that is propitious for co-feeding transmission. The two concepts are so closely linked that previous reviews considered co-feeding transmission as indirect evidence for SAT (Nuttall and Labuda, 2004).

The salivary gland extracts (SGE) from $I$. ricinus ticks suppresses both the innate and acquired immune response in their rodent hosts (Ribeiro and Spielman, 1986; Ribeiro, 1987; Ribeiro et al. 1990; Mejri et al. 2002; Pechová et al. 2002; Guo et al. 2009). This tick-induced immunosuppression is beneficial to the survival and fitness of Borrelia pathogens in the vertebrate host. For example, tick SGE from I. ricinus inhibited the ability of mouse macrophages to kill B. afzelii (Kuthejlová et al. 2001). Gern et al. (1993) provided some of the earliest evidence that the mode of inoculation (tick bite $v s$ needle inoculation) influenced the dynamics of Borrelia infection and the immune response in laboratory mice. Later studies generated additional evidence that Ixodes tick SGE increase infectiousness and transmission of Borrelia pathogens. For example, B. burgdorferi s. s. uses its outer surface protein C (OspC) to bind the tick salivary gland protein Salp15, which allows the pathogen to evade the rodent immune response during the initial phase of the infection (Ramamoorthi et al. 2005). Co-inoculation of Borrelia pathogens with Ixodes tick SGE increased the spirochaete load in the tissues of laboratory rodents (Zeidner et al. 2002). Other studies have shown that spirochaete load in rodent tissues correlates with infectiousness (Wang et al. 2001a) and mouse-to-tick transmission (Raberg, 2012). Interestingly, the SAT effect was specific for the particular combination of Ixodes tick vector and Borrelia pathogen; I. ricinus SGE increased spirochaete load of a European but not an American Borrelia genospecies and vice versa for I. scapularis SGE (Zeidner et al. 2002). Another study found that co-inoculation of B. afzelii spirochaetes with I. ricinus SGE (via needle) resulted in efficient mouse-to-tick transmission to co-feeding nymphs $(57 \%)$ whereas there was no mouse-to-tick transmission in the control mice that were inoculated with $B$. af zelii spirochaetes alone (Pechová et al. 2002). Thus tick-salivary gland products increase both tick-to-mouse and mouseto-tick transmission rates of Borrelia pathogens.

Co-feeding transmission of Borrelia pathogens is different from TBEV because spirochaetes are capable of surviving in the skin for a substantial period of time following inoculation by tick bite. Previous work on B. burgdorferi s. s. showed that Ixodes ticks deposit spirochaetes into the skin where they multiply locally for about 1 week before disseminating to the rest of the body and establishing a systemic infection (Shih et al. 1992). More recent work found evidence for tick SGE effects on spirochaete population growth (Rudolf et al. 2003, 2010) and chemotactic behaviour (Shih et al. 2002), and both of these phenomena could facilitate co-feeding transmission. All three pathogenic Borrelia genospecies (B. garinii, $B$. afzelii and B. burgdorferi s. s.) grow faster in vitro in the presence of $I$. ricinus SGE (Rudolf et al. 2003, 2010). Again, the SAT effect is specific for the tick vector and SGE from non-competent vector ticks such as Dermacentor reticulatus did not enhance spirochaete population growth in vitro (Rudolf et al. 2003). With respect to chemotaxis, work on B. burgdorferi s. s. found that spirochaetes can migrate at substantial speeds $(2 \mathrm{~cm} /$ day $)$ through semi-solid 
media towards Ixodes tick SGE (Shih et al. 2002). The hallmark symptom of Lyme disease, erythema migrans, is further evidence that Borrelia pathogens migrate through the skin before disseminating and establishing a systemic infection. Another study found that B. burgdorferi s. s. spirochaetes respond to vertebrate host neuroendocrine stress hormones such as epinephrine and norepinephrine that are likely to be released at the tick feeding site (Scheckelhoff et al. 2007). Taken together, these studies suggest that the adaptive effects of SGE on spirochaete growth and chemotactic behaviour could easily be co-opted at the host-nymph-larva-pathogen interface to produce co-feeding transmission.

A DAPTIVE SIGNIFICANCE OF CO-FEEDING TRANSMISSION

\section{Theoretical models of co-feeding transmission}

The reproductive number of a parasite, $R_{0}$, is a critical parameter in epidemiology. For directly transmitted infectious diseases, $R_{0}$ is the number of secondary cases produced by a single infected individual when the host population is entirely susceptible. $R_{0}$ therefore measures the capacity of a parasite to invade a population of susceptible hosts. For a tick-borne disease, the interpretation of $R_{0}$ is complicated by the fact that there is a tick-to-host and a host-totick transmission step. However, in this case $R_{0}$ represents the number of infected ticks produced by one infected tick in the previous generation. Recent theoretical work has used the next-generation matrix method to calculate $R_{0}$ for tick-borne pathogens (Hartemink et al. 2008; Harrison et al. 2011; Harrison and Bennett, 2012). These theoretical analyses generally show that whereas co-feeding transmission is critical for TBEV, systemic transmission is sufficient for Borrelia pathogens to invade a population of susceptible hosts (Hartemink et al. 2008; Harrison et al. 2011; Harrison and Bennett, 2012). When ticks had a coincident, aggregated distribution, the value of $R_{0}$ increased by 2.07 to $6.68 \%$ depending on the proportion of competent hosts (10-100\%) from which the ticks derive their meal (Harrison and Bennett, 2012). This analysis suggests that a mutant genotype capable of both systemic and co-feeding transmission would be able to outcompete and eventually displace a resident genotype that uses systemic transmission alone. Thus co-feeding transmission may give Borrelia pathogens a competitive advantage in the context of mixed infections (see below).

Randolph et al. (1996) were the first to point out that the duration of infection is the main reason why TBEV (2 days) is critically dependent on cofeeding transmission whereas Borrelia pathogens (120 days) are not. Elasticity analysis of the next generation matrices of tick-borne pathogens have confirmed that $R_{0}$ value of tick-borne pathogens is highly dependent on the duration of systemic infection (Hartemink et al. 2008). Changing the duration of systemic infection from 120 days to 2 days essentially switched the major contribution to $R_{0}$ from systemic to co-feeding transmission (Randolph et al. 1996). It should be pointed out that all recent theories (Hartemink et al. 2008; Harrison et al. 2011; Harrison and Bennett, 2012) have used the same parameter estimates from the 1996 analysis by Randolph et al. All these theoretical studies therefore assume that the average duration of Borrelia infection is 120 days and that the host-to-tick transmission rate is $50 \%$ and constant over the age of the infection (Hartemink et al. 2008; Harrison et al. 2011; Harrison and Bennett, 2012). These parameter estimates were taken from early studies on competent rodent reservoir hosts that documented chronic infection and high rates of mouse-to-tick transmission (Donahue et al. 1987; Gern et al. 1994). However, other studies have shown that the mouse-to-tick transmission rate can decrease rapidly over time (Lindsay et al. 1997; Derdakova et al. 2004; Hanincova et al. 2008). For example, mouse-to-tick transmission of B. burgdorferi s. s. strain B348 declined from 80 to $0 \%$ over 42 days (Derdakova et al. 2004). Another study found that mouse-to-tick transmission declined from 75 to $26 \%$ in only 21 days (Lindsay et al. 1997). Incorporating this shorter duration of infectiousness would obviously increase the importance of co-feeding transmission to the fitness of Borrelia pathogens.

\section{Life history perspective of co-feeding transmission}

From a life history theory perspective, the distinction between co-feeding and systemic transmission is similar to the trade-off between early and late reproduction that is common to all organisms (Stearns, 1992). On the one hand, systemic transmission is more efficient than co-feeding transmission suggesting that spirochaetes should maximize investment in systemic transmission to achieve the highest possible fitness. On the other hand, vulnerable reservoir hosts such as rodents have many sources of mortality (accidents, predators and disease) and dead rodents cannot transmit systemic infections. In addition, systemically infected individuals may disperse to new habitats that do not support larval ticks to complete the systemic infection cycle. Thus investment in cofeeding transmission may represent a bet-hedging strategy for the spirochaete because the future is uncertain and a systemic infection may not always bear fruit. As mentioned previously, numerous studies on $B$. burgdorferi $s$. $s$. have shown that the efficiency of mouse-to-larva transmission decreases with the age of the systemic infection in the reservoir host (Lindsay et al. 1997; Derdakova et al. 2004; Hanincova et al. 2008). Thus the fitness advantage of 
systemic transmission appears to decline with the age of the infection.

\section{Co-feeding transmission and the evasion of host immunity}

Co-feeding transmission allows tick-borne pathogens to escape the host immune response that is directed at systemic infections. Immune evasion via co-feeding was first demonstrated in TBEV; the virus was still able to achieve co-feeding transmission on rodents that had developed virus-specific neutralizing antibodies in response to an earlier viraemic infection (Labuda et al. 1997). From an epidemiological perspective, hosts that had acquired resistance to systemic infection were still competent for co-feeding transmission.

The host immune system of vertebrate reservoir hosts likewise poses a major challenge for $B$. burgdorferi s. $l$. pathogens. Both the innate and the acquired arms of the vertebrate immune system can prevent the establishment of systematic spirochaete infections. The innate complement system is a collection of host serum proteins that assemble on the pathogen surface to form the so-called membrane attack complex, which is capable of puncturing the plasma membranes resulting in cell lysis and pathogen death. In the European Lyme disease system, host complement appears to play an important role in structuring associations between Borrelia pathogens and their vertebrate hosts (Kurtenbach et al. 1998b, 2002a). Borrelia afzelii and B. burgdorferi s. s. are tolerant of rodent but not bird complement (Kurtenbach et al. 1998b, 2002a) and are mostly found in rodent reservoir hosts (Humair et al. 1995; Humair and Gern, 1998; Kurtenbach et al. 1998a; Huegli et al. 2002; Hanincova et al. 2003a). Conversely, B. garinii and B. valaisiana are tolerant of bird but not rodent complement (Kurtenbach et al. 1998b, 2002a) and are mostly found in birds (Humair et al. 1998; Kurtenbach et al. 1998a, 2002b; Hanincova et al. 2003b; Taragel'ová et al. 2008). Vertebrate complement therefore plays an important role in restricting the range of reservoir hosts that are competent for systemic transmission.

Since its initial discovery, numerous authors have suggested that co-feeding transmission may allow Borrelia pathogens to derive some fitness gains from the otherwise incompetent hosts (Randolph et al. 1996; Gern et al. 1998) and there is some evidence to suggest that this is the case. For example, $B$. garinii and $B$. valaisiana achieved transmission between immature Ixodes ticks co-feeding on laboratory mice even though these Borrelia genospecies are generally killed by rodent complement (Sato and Nakao, 1997; $\mathrm{Hu}$ et al. 2003). A recent study on birds found that ticks co-feeding with other ticks were four times more likely to be infected with B. afzelii (Hasle, 2013). To date, the most convincing example comes from the northwest UK where co-feeding I. ricinus ticks maintain Borrelia pathogens in populations of sheep that are otherwise refractory to developing systemic spirochaete infections (Ogden et al. 1997).

Cervids are of particular interest with respect to co-feeding transmission because these animals are known to feed a large number of both immature and adult ticks (Jaenson and Talleklint, 1992; Matuschka et al. 1993). Recent work using host blood meal identification has confirmed the importance of deer as hosts for immature ticks in both North America and Europe. These studies found that $26 \cdot 2-40 \cdot 0 \%$ of all questing Ixodes nymphs obtained their blood meals from deer (and related artiodactyls) (Morán Cadenas et al. 2007; Scott et al. 2012). Earlier work on cervids suggested that these animals rarely transmitted B. burgdorferi $s$. $l$. to Ixodes ticks (Telford et al. 1988; Jaenson and Talleklint, 1992; Matuschka et al. 1993) but these studies did not consider the possibility of co-feeding transmission. A recent field study found that all stages of I. ricinus were highly clustered on roe deer suggesting that these animals could provide a platform for co-feeding transmission (Kiffner et al. 2011). An earlier field study on a variety of cervids found that $28 \cdot 0 \%(14 / 50)$ of the animals had skin biopsies that tested positive for B. burgdorferi s. $l$. spirochaetes (Pichon et al. 2000). This study suggested that Borrelia spirochaetes can survive in cervid skin for a considerable period of time because the animals were shot in the winter when there is no tick questing activity (Pichon et al. 2000). A study on sika deer found that $I$. persulcatus ticks co-feeding on deerskin had a prevalence of $B$. burgdorferi $s$. $l$. that was five times higher than the background prevalence in questing nymphs (Kimura et al. 1995). The authors also showed that the spirochaetes in the sika deer-derived ticks were viable by culturing them in BSK medium (Kimura et al. 1995). This result was important because other in vitro studies have shown that Borrelia pathogens are generally killed by the ungulate complement (Kurtenbach et al. 1998b, 2002a). Host blood meal identification in questing ticks has found contradictory results with respect to whether deer can transmit viable spirochaete infections (Gray et al. 1999; Pichon et al. 2003, 2005; Morán Cadenas et al. 2007). An earlier study in Ireland found that all nymphs that had fed on deer were devoid of Borrelia spirochaetes (Gray et al. 1999). In contrast, a later study in Switzerland, found that that $18 \cdot 4 \%(16 / 87)$ of all infections with $B$. burgdorferi $s$. $l$. occurred in nymphal ticks that had fed on artiodactyls (deer and chamois) (see Table 4 in Morán Cadenas et al. 2007). In summary, whereas earlier studies concluded that deer rarely transmitted $B$. burgdorferi $s$. $l$. to feeding ticks (Telford et al. 1988; Jaenson and Talleklint, 1992; Matuschka et al. 1993) the more recent work on host blood meal identification suggests that cervids can transmit viable spirochaete infections to Ixodes 
nymphs (Morán Cadenas et al. 2007). The host blood meal identification work currently suffers from low sensitivity (the blood meal is not identifiable for many questing ticks) and so the sample sizes are still relatively low. Future studies will hopefully establish with more certainty whether co-feeding transmission on cervids makes an important contribution to Borrelia fitness.

The acquired immune response can also prevent the establishment of systemic infections in otherwise competent reservoir hosts. Active and passive immunization of rodents with Borrelia pathogens induces an antibody response that prevents secondary infection by antigenically similar spirochaete strains (Johnson et al. 1986a, b; Piesman et al. 1997; Barthold 1999). In a natural population of P. leucopus mice, the anti-Borrelia antibody profile becomes increasingly hostile to new systemic infections over the course of the summer (Bunikis et al. 2004). Thus the likelihood that a tick-borne spirochaete can find a susceptible reservoir host becomes vanishingly small at the end of the summer. However, tick-borne Borrelia pathogens may still be able to derive some fitness gains from immune hosts if co-feeding transmission allows spirochaetes to escape the antibody response induced against a previous infection. A recent study on another tick-borne bacterial pathogen, the gram-negative, intracellular $A$. phagocytophilum, found that acquired immunity in $P$. leucopus reduced but did not eliminate co-feeding transmission (Levin and Fish, 2000). Surprisingly, to date, no one has tested whether acquired immunity reduces the efficiency of co-feeding transmission in Borrelia pathogens. The demonstration that acquired immunity blocks systemic but not co-feeding transmission would demonstrate the adaptive advantage of the latter in the context of acquired immunity in the vertebrate host.

\section{Advantage of co-feeding transmission in multiple infections}

Co-feeding may be particularly important in the context of mixed infections where competition among strains will select for any additional transmission advantage. Previous studies have repeatedly shown that mixed infections of Borrelia strains are common in both the tick vector (Qiu et al. 1997, 2002; Wang et al. 1999; Pérez et al. 2011; MacQueen et al. 2012) and the rodent reservoir (Brisson and Dykhuizen, 2004; Swanson and Norris, 2008; Pérez et al. 2011; Andersson et al. 2013). A recent experimental infection study found that there was genetic variation in co-feeding transmission among nine strains of B. afzelii (Tonetti and Gern, 2011). Of the six strains that were capable of this mode of transmission, the efficacy of co-feeding transmission ranged between $3 \cdot 8$ and $66 \cdot 2 \%$ (Tonetti and Gern, 2011). The B. afzelii strain that had the highest rate of co-feeding transmission (strain YU) had been discovered in a previous field study where it dominated the community of $B$. afzelii strains at the site with the higher level of coincident feeding between nymphal and larval ticks (Pérez et al. 2011). This field study thus suggested that co-feeding transmission can shape the community of B. afzelii strains, although there are alternative explanations (Pérez et al. 2011). For example, strains with high co-feeding transmission also have high tick-to-host and systemic (host-to-tick) transmission (Tonetti and Gern, 2011) suggesting that some B. afzelii strains are simply better at all the components of the spirochaete life cycle. The demonstration that there is genetic variation in co-feeding transmission among Borrelia strains is important because it shows that this trait can evolve by natural selection (Tonetti and Gern, 2011).

\section{Co-feeding facilitates co-occurrence of ecologically separated Borrelia species}

Co-feeding transmission may facilitate encounters between Borrelia species that occupy different ecological niches in the community of vertebrate reservoir hosts. In Europe, as explained previously, the two most common Borrelia species, B. afzelii and $B$. garinii, are adapted to rodents and birds, respectively (Gern and Humair, 1998; Humair and Gern, 2000; Gern and Humair, 2002), and this hostpathogen specificity is mediated by vertebrate complement (Kurtenbach et al. 1998b, 2002a). Statistical analysis of the frequencies of single and double infections in wild ticks supports the hypothesis that $B$. afzelii and B. garinii occupy different ecological niches (Kurtenbach et al. 2001; Pichon et al. 2003; Herrmann et al. 2013). However, this ecological separation is not $100 \%$ complete and the two Borrelia species, by virtue of being common, encounter each other in the tick vector with appreciable frequency (Kurtenbach et al. 2001; Pichon et al. 2003; Herrmann et al. 2013). Co-feeding transmission is a plausible explanation for these co-infected nymphs (Kurtenbach et al. 2001; Pichon et al. 2003; Herrmann et al. 2013). For example, a larva may co-feed with a $B$. garinii-infected nymph on a $B$. afzelii-infected rodent reservoir host. In this example, the larva acquires $B$. garinii from the cofeeding nymph and $B$. afzelii from the rodent reservoir. The larval tick also ingests the host complement, which is active in the tick midgut (Papatheodorou and Brossard, 1987). The complement hypothesis of vertebrate host-Borrelia pathogen specificity predicts that the complement of the reservoir host (i.e. the rodent) would reduce the spirochaete load of the co-feeding-acquired Borrelia species (i.e. B. garinii) inside the larval tick. Interestingly, a recent study on the joint spirochete loads of co-infecting Borrelia species inside I. ricinus 
nymphs found evidence consistent with this complement hypothesis (Herrmann et al. 2013). In summary, co-feeding transmission explains the cooccurrence in nymphs of Borrelia species that occupy different niches in the community of vertebrate hosts. These occasional encounters in the tick vector can have important macro-evolutionary consequences for Borrelia pathogens. For example, genetic analysis of the ospC gene in B. burgdorferi s. s., B. afzelii and $B$. garinii, found numerous instances of horizontal transfer between these three Borrelia species (Baranton et al. 2001). Thus co-feeding transmission may facilitate genetic exchange between Borrelia pathogens that are otherwise genetically isolated.

\section{Concluding remarks}

Future studies should investigate co-feeding transmission in the Lyme disease systems where it is likely to be important. The synchronized phenologies of immature $I$. ricinus ticks in Europe and the common occurrence of nymphal and larval ticks on the same host suggest that co-feeding transmission is more important in European than North American Lyme disease systems. Previous studies on B. afzelii and the ease of working with rodent models suggest that the $B$. afzelii pathogen-I. ricinus tick vector-is the most tractable system for studying the ecological significance of co-feeding transmission. Future studies should test whether co-feeding transmission allows Borrelia pathogens to escape the acquired immune response of their vertebrate hosts and whether this mode of transmission confers a fitness advantage in the context of mixed infections.

\section{ACKNOWLEDGEMENTS}

Thanks to three anonymous reviewers for comments on this manuscript. A special thanks to Lise Gern for her comments and support in writing this manuscript.

\section{FINANCIAL SUPPORT}

This work was supported by a grant from the Swiss National Science Foundation (FN 31003A_141153).

\section{REFERENCES}

Alekseev, A. N. and Chunikhin, S.P. (1990). The exchange of the tick-borne encephalitis virus between ixodid ticks feeding jointly on animals with a subthreshold level of viremia. Meditsinskaia Parazitologiia (Mosk) 2, 48-50.

Andersson, M., Scherman, K., Raberg, L. and Råberg, L. (2013). Multiple-strain infections of Borrelia afzelii: a role for within-host interactions in the maintenance of antigenic diversity? The American Naturalist 181, 545-554

Baranton, G., Seinost, G., Theodore, G., Postic, D. and Dykhuizen, D. (2001). Distinct levels of genetic diversity of Borrelia burgdorferi are associated with different aspects of pathogenicity. Research in Microbiology 152, 149-156.

Barthold, S. W. (1999). Specificity of infection-induced immunity among Borrelia burgdorferi sensu lato species. Infection and Immunity 67, 36-42.
Brisson, D. and Dykhuizen, D. E. (2004). ospC diversity in Borrelia burgdorferi: different hosts are different niches. Genetics 168, 713-722.

Brossard, M. and Wikel, S. K. (2004). Tick immunobiology. Parasitology 129(Suppl), S161-176.

Brunner, J. L. and Ostfeld, R. S. (2008). Multiple causes of variable tick burdens on small-mammal hosts. Ecology 89, 2259-2272.

Bunikis, J., Tsao, J., Luke, C. J., Luna, M. G., Fish, D. and Barbour, A. G. (2004). Borrelia burgdorferi infection in a natural population of Peromyscus leucopus mice: a longitudinal study in an area where Lyme borreliosis is highly endemic. Fournal of Infectious Diseases 189, 1515-1523.

Burri, C., Bastic, V., Maeder, G., Patalas, E. and Gern, L. (2011). Microclimate and the zoonotic cycle of tick-borne encephalitis virus in Switzerland. Fournal of Medical Entomology 48, 615-627.

Charon, N., Cockburn, A., Li, C., Liu, J., Miller, K., Miller, M., Motaleb, M. and Wolgemuth, C. (2012). The unique paradigm of spirochete motility and chemotaxis. Annual Review of Microbiology 66, 349-370.

Craine, N. G., Randolph, S. E. and Nuttall, P. A. (1995). Seasonal variation in the role of grey squirrels as hosts of Ixodes ricinus, the tick vector of the Lyme disease spirochaete, in a British woodland. Folia Parasitologica 42, 73-80.

Daniels, T. J. and Fish, D. (1990). Spatial distribution and dispersal of unfed larval Ixodes dammini (Acari, Ixodidae) in southern New York. Environmental Entomology 19, 1029-1033.

Derdakova, M., Dudioak, V., Brei, B., Brownstein, J. S., Schwartz, I. and Fish, D. (2004). Interaction and transmission of two Borrelia burgdorferi sensu stricto strains in a tick-rodent maintenance system. Applied and Environmental Microbiology 70, 6783-6788.

Devevey, G. and Brisson, D. (2012). The effect of spatial heterogeneity on the aggregation of ticks on white-footed mice. Parasitology 139, 915-925.

Donahue, J. G., Piesman, J. and Spielman, A. (1987). Reservoir competence of white-footed mice for Lyme disease spirochetes. American Fournal of Tropical Medicine and Hygiene 36, 92-96.

Gatewood, A. G., Liebman, K. A., Vourc'h, G., Bunikis, J., Hamer, S. A., Cortinas, R., Melton, F., Cislo, P., Kitron, U., Tsao, J., Barbour, A. G., Fish, D. and Diuk-Wasser, M. A. (2009). Climate and tick seasonality are predictors of Borrelia burgdorferi genotype distribution. Applied and Environmental Microbiology 75, 2476-2483.

Gern, L. and Humair, P. F. (1998). Natural history of Borrelia burgdorferi sensu lato. Wiener Klinische Wochenschrift 110, 856-858.

Gern, L. and Humair, P.-F. (2002). Ecology of Borrelia burgdorferi sensu lato in Europe. In Lyme Borreliosis: Biology, Epidemiology, and Control (ed. Gray, J. S., Kahl, O., Lane, R. S. and Stanek, G.), pp. 149-174. CABI Publishing, Wallingford, Oxfordshire, UK.

Gern, L. and Rais, O. (1996). Efficient transmission of Borrelia burgdorferi between cofeeding Ixodes ricinus ticks (Acari: Ixodidae). Fournal of Medical Entomology 33, 189-192.

Gern, L., Schaible, U. E. and Simon, M. M. (1993). Mode of inoculation of the Lyme disease agent Borrelia burgdorferi influences infection and immune responses in inbred strains of mice. Fournal of Infectious Diseases 167, 971-975.

Gern, L., Siegenthaler, M., Hu, C. M., Leuba-Garcia, S., Humair, P. F. and Moret, J. (1994). Borrelia burgdorferi in rodents (Apodemus flavicollis and A. sylvaticus): duration and enhancement of infectivity for Ixodes ricinus ticks. European Fournal of Epidemiology 10, 75-80.

Gern, L., Estrada-Pena, A., Frandsen, F., Gray, J. S., Jaenson, T. G. T., Jongejan, F., Kahl, O., Korenberg, E., Mehl, R. and Nuttall, P. A. (1998). European reservoir hosts of Borrelia burgdorferi sensu lato. Zentralblatt Fur Bakteriologie - International Fournal of Medical Microbiology Virology Parasitology and Infectious Diseases 287, 196-204. Gray, J. S., Kirstein, F., Robertson, J. N., Stein, J. and Kahl, O. (1999). Borrelia burgdorferi sensu lato in Ixodes ricinus ticks and rodents in a recreational park in south-western Ireland. Experimental and Applied Acarology 23, 717-729.

Guo, X., Booth, C., Paley, M., Wang, X., DePonte, K., Fikrig, E., Narasimhan, S. and Montgomery, R. (2009). Inhibition of neutrophil function by two tick salivary proteins. Infection and Immunity 77, 23202329.

Hanincova, K., Schafer, S. M., Etti, S., Sewell, H. S., Taragelova, V., Ziak, D., Labuda, M. and Kurtenbach, K. (2003a). Association of Borrelia afzelii with rodents in Europe. Parasitology 126, 11-20.

Hanincova, K., Taragelova, V., Koci, J., Schafer, S. M., Hails, R., Ullmann, A. J., Piesman, J., Labuda, M. and Kurtenbach, K. (2003b). Association of Borrelia garinii and B. valaisiana with songbirds in Slovakia. Applied and Environmental Microbiology 69, 2825-2830.

Hanincova, K., Ogden, N. H., Diuk-Wasser, M., Pappas, C. J., Iyer, R., Fish, D., Schwartz, I. and Kurtenbach, K. (2008). Fitness variation of 
Borrelia burgdorferi sensu stricto strains in mice. Applied and Environmental Microbiology 74, 153-157.

Harrison, A. and Bennett, N. (2012). The importance of the aggregation of ticks on small mammal hosts for the establishment and persistence of tick-borne pathogens: an investigation using the $\mathrm{R}(0)$ model. Parasitology 139, 1605-1613

Harrison, A., Montgomery, W. I. and Bown, K. J. (2011). Investigating the persistence of tick-borne pathogens via the R-0 model. Parasitology 138 896-905.

Hartemink, N. A., Randolph, S.E., Davis, S.A. and Heesterbeek, J. A. P. (2008). The basic reproduction number for complex disease systems: defining R-0 for tick-borne infections. American Naturalist 171, 743-754.

Hasle, G. (2013). Transport of ixodid ticks and tick-borne pathogens by migratory birds. Frontiers in Cellular and Infection Microbiology 3, 48 Herrmann, C., Gern, L. and Voordouw, M. (2013). Species cooccurrence patterns among Lyme borreliosis pathogens in the tick vector Ixodes ricinus. Applied and Environmental Microbiology, 79, 7273-7280.

Higgs, S., Schneider, B. S., Vanlandingham, D. L., Klingler, K. A and Gould, E. A. (2005). Nonviremic transmission of West Nile virus. Proceedings of the National Academy of Sciences of the United States of America 102, 8871-8874.

Hu, C. M., Cheminade, Y., Perret, J. L., Weynants, V., Lobet, Y. and Gern, L. (2003). Early detection of Borrelia burgdorferi sensu lato infection in Balb/c mice by co-feeding Ixodes ricinus ticks. International Fournal of Medical Microbiology 293, 421-426.

Huegli, D., Hu, C. M., Humair, P. F., Wilske, B. and Gern, L. (2002) Apodemus species mice are reservoir hosts of Borrelia garinii OspA serotype 4 in Switzerland. Fournal of Clinical Microbiology 40, 4735-4737.

Hughes, V. L. and Randolph, S. E. (2001). Testosterone depresses innate and acquired resistance to ticks in natural rodent hosts: a force for aggregated distributions of parasites. The Fournal of Parasitology 87, 49-54.

Humair, P.F. and Gern, L. (1998). Relationship between Borrelia burgdorferi sensu lato species, red squirrels (Sciurus vulgaris) and Ixodes ricinus in enzootic areas in Switzerland. Acta Tropica 69(3), 213-227. Humair, P. F. and Gern, L. (2000). The wild hidden face of Lyme borreliosis in Europe. Microbes and Infection 2, 915-922.

Humair, P. F., Péter, O., Wallich, R. and Gern, L. (1995). Strain variation of Lyme disease spirochetes isolated from Ixodes ricinus ticks and rodents collected in two endemic areas in Switzerland. Fournal of Medical Entomology 32, 433-438.

Humair, P. F., Postic, D., Wallich, R. and Gern, L. (1998). An avian reservoir (Turdus merula) of the Lyme borreliosis spirochetes. Zentralblat Fur Bakteriologie - International Fournal of Medical Microbiology Virology Parasitology and Infectious Diseases 287, 521-538.

Jaenson, T. G. T. and Talleklint, L. (1992). Incompetence of roe deer as reservoirs of the Lyme borreliosis spirochete. Fournal of Medical Entomology 29, 813-817.

Johnson, R. C., Kodner, C. and Russell, M. (1986a). Active immunization of hamsters against experimental infection with Borrelia burgdorferi. Infection and Immunity 54, 897-898.

Johnson, R. C., Kodner, C. and Russell, M. (1986b). Passive immunization of hamsters against experimental infection with the Lyme disease spirochete. Infection and Immunity 53, 713-714.

Jones, L. D., Davies, C. R., Steele, G. M. and Nuttall, P. A. (1987). A novel mode of arbovirus transmission involving a nonviremic host. Science 237, 775-777.

Keesing, F., Brunner, J., Duerr, S., Killilea, M., LoGiudice, K., Schmidt, K., Vuong, H. and Ostfeld, R. S. (2009). Hosts as ecological traps for the vector of Lyme disease. Proceedings of the Royal Society Biological Sciences Series B 267, 3911-3919.

Kiffner, C., Lodige, C., Alings, M., Vor, T. and Ruhe, F. (2011) Attachment site selection of ticks on roe deer, Capreolus capreolus. Experimental and Applied Acarology 53, 79-94

Kimura, K., Isogai, E., Isogai, H., Kamewaka, Y., Nishikawa, T., Ishii, N. and Fujii, N. (1995). Detection of Lyme disease spirochetes in the skin of naturally infected wild sika deer (Cervus nippon yesoensis) by PCR. Applied and Environmental Microbiology 61, 1641-1642.

Kjelland, V., Ytrehus, B., Vikoren, T., Stuen, S., Skarpaas, T. Vikørren, T. and Slettan, A. (2011). Borrelia burgdorferi sensu lato detected in skin of Norwegian mountain hares (Lepus timidus) without signs of dissemination. Fournal of Wildlife Diseases 47, 293-299.

Kocan, K. and de la Fuente, J. (2003). Co-feeding studies of ticks infected with Anaplasma marginale. Veterinary Parasitology 112, 295-305.

Kurtenbach, K., Peacey, M., Rijpkema, S. G. T., Hoodless, A. N., Nuttall, P. A. and Randolph, S. E. (1998a). Differential transmission of the genospecies of Borrelia burgdorferi sensu lato by game birds and small rodents in England. Applied and Environmental Microbiology 64, 1169-1174.
Kurtenbach, K., Sewell, H.S., Ogden, N.H., Randolph, S. E. and Nuttall, P. A. (1998b). Serum complement sensitivity as a key factor in Lyme disease ecology. Infection and Immunity 66, 1248-1251.

Kurtenbach, K., De Michelis, S., Sewell, H. S., Etti, S., Schafer, S. M., Hails, R., Collares-Pereira, M., Santos-Reis, M., Hanincova, K., Labuda, M., Bormane, A. and Donaghy, M. (2001). Distinct combinations of Borrelia burgdorferi sensu lato genospecies found in individual questing ticks from Europe. Applied and Environmental Microbiology 67, 4926-4929.

Kurtenbach, K., De Michelis, S., Etti, S., Schafer, S. M., Sewell, H. S. Brade, V. and Kraiczy, P. (2002a). Host association of Borrelia burgdorferi sensu lato - the key role of host complement. Trends in Microbiology 10 74-79.

Kurtenbach, K., Schafer, S. M., Sewell, H.S., Peacey, M., Hoodless, A., Nuttall, P. A. and Randolph, S. E. (2002b). Differentia survival of Lyme borreliosis spirochetes in ticks that feed on birds. Infection and Immunity 70, 5893-5895.

Kurtenbach, K., Hanincova, K., Tsao, J. I., Margos, G., Fish, D. and Ogden, N. H. (2006). Fundamental processes in the evolutionary ecology of Lyme borreliosis. Nature Reviews Microbiology 4, 660-669.

Kuthejlová, M., Kopecky, J., Stepanova, G., Macela, A., Kopecký, J and Stepánová, G. (2001). Tick salivary gland extract inhibits killing of Borrelia afzelii spirochetes by mouse macrophages. Infection and Immunity 69, 575-578.

Labuda, M., Kozuch, O., Eleckova, E., Williams, T., Nuttall, P. A., Elecková, E., Zuffová, E. and Sabó, A. (1993a). Non-viraemic transmission of tick-borne encephalitis virus: a mechanism for arbovirus survival in nature. Experientia 49, 802-805.

Labuda, M., Williams, T., Danielova, V., Jones, L. D. and Nuttall, P. A. (1993b). Efficient transmission of tick-borne encephalitis virus between cofeeding ticks. Fournal of Medical Entomology 30, 295-299. Labuda, M., Williams, T., Jones, L. D. and Nuttall, P. A. (1993c). Enhancement of tick-borne encephalitis virus transmission by tick salivary gland extracts. Medical and Veterinary Entomology 7, 193-196.

Labuda, M., Zuffova, E., Kozuch, O., Fuchsberger, N., Austyn, J. M., Lysy, J. and Nuttall, P. A. (1996). Importance of localized skin infection in tick-borne encephalitis virus transmission. Virology 219, 357-366.

Labuda, M., Kozuch, O., Zuffova, E., Eleckova, E., Hails, R.S. and Nuttall, P.A. (1997). Tick-borne encephalitis virus transmission between ticks cofeeding on specific immune natural rodent hosts. Virology 235, 138-143.

Levin, M. L. and Fish, D. (2000). Immunity reduces reservoir host competence of Peromyscus leucopus for Ehrlichia phagocytophila. Infection and Immunity 68, 1514-1518.

Lindsay, L. R., Barker, I. K., Surgeoner, G. A., McEwen, S. A. and Campbell, G. D. (1997). Duration of Borrelia burgdorferi infectivity in white-footed mice for the tick vector Ixodes scapularis under laboratory and field conditions in Ontario. Fournal of Wildlife Diseases 33, 766-775.

MacQueen, D., Lubelczyk, C., Elias, S., Cahill, B., Mathers, A., Lacombe, E., Rand, P. and Smith, R. (2012). Genotypic diversity of an emergent population of Borrelia burgdorferi at a coastal Maine island recently colonized by Ixodes scapularis. Vector Borne and Zoonotic Diseases 12, 456-461.

Matuschka, F. R., Heiler, M., Eiffert, H., Fischer, P., Lotter, H. and Spielman, A. (1993). Diversionary role of hoofed game in the transmission of Lyme disease spirochetes. American fournal of Tropical Medicine and Hygiene 48, 693-699.

Mead, D. G., Ramberg, F. B., Besselsen, D. G. and Mare, C. J. (2000). Transmission of vesicular stomatitis virus from infected to noninfected black flies co-feeding on nonviremic deer mice. Science 287, 485-487

Mejri, N., Rutti, B. and Brossard, M. (2002). Immunosuppressive effects of Ixodes ricinus tick saliva or salivary gland extracts on innate and acquired immune response of BALB/c mice. Parasitology Research 88, 192-197. Montgomery, R. R., Nathanson, M. H. and Malawista, S. E. (1993). The fate of Borrelia burgdorferi, the agent for Lyme disease, in mouse macrophages. Destruction, survival, recovery. The Fournal of Immunology 150, 909-915

Morán Cadenas, F. M., Rais, O., Humair, P. F., Douet, V., Moret, J. and Gern, L. (2007). Identification of host bloodmeal source and Borrelia burgdorferi sensu lato in field-collected Ixodes ricinus ticks in Chaumont (Switzerland). Fournal of Medical Entomology 44, 1109-1117.

Nuttall, P. A. (1999). Pathogen-tick-host interactions: Borrelia burgdorferi and TBE virus. Zentralblatt für Bakteriologie 289, 492-505.

Nuttall, P. A. and Labuda, M. (2003). Dynamics of infection in tick vectors and at the tick-host interface. Flaviviruses: Pathogenesis and Immunity 60, 233-272.

Nuttall, P. A. and Labuda, M. (2004). Tick-host interactions: salivaactivated transmission. Parasitology 129, S177-S189. 
Ogden, N. H., Nuttall, P. A. and Randolph, S. E. (1997). Natural Lyme disease cycles maintained via sheep by cofeeding ticks. Parasitology 115, 591-599.

Ogden, N.H., Hailes, R.S. and Nuttall, P.A. (1998a). Interstadial variation in the attachment sites of Ixodes ricinus ticks on sheep. Experimental and Applied Acarology 22, 227-232.

Ogden, N. H., Kurtenbach, K. and Nuttall, P. A. (1998b). Interstadial and infestation level-dependent variation in the transmission efficiency of Borrelia burgdorferi from mice to Ixodes ricinus ticks. Experimental and Applied Acarology 22, 367-372.

Ogden, N. H., Bigras-Poulin, M., O’Callaghan, C. J., Barker, I. K., Kurtenbach, K., Lindsay, L. R. and Charron, D. (2007). Vector seasonality, host infection dynamics and fitness of pathogens transmitted by the tick Ixodes scapularis. Parasitology 134, 209-227.

Papatheodorou, V. and Brossard, M. (1987). C-3 levels in the sera of rabbits infested and reinfested with Ixodes ricinus $\mathrm{L}$ and in midguts of fed ticks. Experimental and Applied Acarology 3, 53-59.

Patrican, L. A. (1997). Acquisition of Lyme disease spirochetes by cofeeding Ixodes scapularis ticks. The American journal of tropical medicine and hygiene 57, 589-593.

Pechová, J., Stepanova, G., Kovar, L., Kopecky, J., Kovár, L. and Kopecký, J. (2002). Tick salivary gland extract-activated transmission of Borrelia afzelii spirochaetes. Folia Parasitologica 49, 153-159.

Pérez, D., Kneubühler, Y., Rais, O., Jouda, F. and Gern, L. (2011). Borrelia afzelii ospC genotype diversity in Ixodes ricinus questing ticks and ticks from rodents in two Lyme borreliosis endemic areas: contribution of co-feeding ticks. Ticks and Tick-borne Diseases 2, 137-142.

Perkins, S. E., Cattadori, I. M., Tagliapietra, V., Rizzoli, A.P. and Hudson, P. J. (2003). Empirical evidence for key hosts in persistence of a tick-borne disease. International fournal for Parasitology 33, 909-917. Pichon, B., Gilot, B. and Perez-Eid, C. (2000). Detection of spirochaetes of Borrelia burgdorferi complex in the skin of cervids by PCR and culture. European Fournal of Epidemiology 16, 869-873.

Pichon, B., Egan, D., Rogers, M. and Gray, J. (2003). Detection and identification of pathogens and host DNA in unfed host-seeking Ixodes ricinus L. (Acari: Ixodidae). Fournal of Medical Entomology 40, 723-731.

Pichon, B., Rogers, M., Egan, D. and Gray, J. (2005). Blood-meal analysis for the identification of reservoir hosts of tick-borne pathogens in Ireland. Vector-Borne and Zoonotic Diseases 5, 172-180.

Piesman, J. and Happ, C. M. (2001). The efficacy of co-feeding as a means of maintaining Borrelia burgdorferi: a North American model system. Fournal of Vector Ecology 26, 216-220.

Piesman, J., Dolan, M. C., Happ, C. M., Luft, B. J., Rooney, S. E., Mather, T. N. and Golde, W. T. (1997). Duration of immunity to reinfection with tick-transmitted Borrelia burgdorferi in naturally infected mice. Infection and Immunity 65, 4043-4047.

Qiu, W. G., Bosler, E. M., Campbell, J. R., Ugine, G. D., Wang, I. N., Luft, B. J. and Dykhuizen, D. E. (1997). A population genetic study of Borrelia burgdorferi sensu stricto from eastern Long Island, New York, suggested frequency-dependent selection, gene flow and host adaptation. Hereditas 127, 203-216.

Qiu, W. G., Dykhuizen, D. E., Acosta, M. S. and Luft, B. J. (2002). Geographic uniformity of the Lyme disease spirochete (Borrelia burgdorferi) and its shared history with tick vector (Ixodes scapularis) in the northeastern United States. Genetics 160, 833-849.

Raberg, L. (2012). Infection intensity and infectivity of the tickborne pathogen Borrelia afzelii. Fournal of Evolutionary Biology 25 , 1448-1453

Ramamoorthi, N., Narasimhan, S., Pal, U., Bao, F. K., Yang, X. F. F., Fish, D., Anguita, J., Norgard, M. V., Kantor, F. S., Anderson, J. F., Koski, R. A. and Fikrig, E. (2005). The Lyme disease agent exploits a tick protein to infect the mammalian host. Nature 436, 573-577.

Randolph, S. E. (1975). Patterns of distribution of the tick Ixodes trianguliceps Birula on its host. Fournal of Animal Ecology 44, 451-474. Randolph, S. E. (1998). Ticks are not insects: consequences of contrasting vector biology for transmission potential. Parasitology Today 14, 186-192. Randolph, S. E. (2009). Tick-borne disease systems emerge from the shadows: the beauty lies in molecular detail, the message in epidemiology. Parasitology 136, 1403-1413.

Randolph, S. E. (2011). Transmission of tick-borne pathogens between cofeeding ticks: Milan Labuda's enduring paradigm. Ticks and Tick-borne Diseases 2, 179-182

Randolph, S. E. and Gern, L. (2003). Co-feeding transmission and its contribution to the perpetuation of the Lyme disease spirochete Borrelia afzelii. Emerging Infectious Diseases 9, 893-894.

Randolph, S. E. and Rogers, D. J. (2000). Fragle transmission cycles of tick-borne encephalitis virus may be disrupted by predicted climate change. Proceedings of the Royal Society Biological Sciences Series B 267, 1741-1744.
Randolph, S. E. and Sumilo, D. (2007). Tick-borne encephalitis in Europe: dynamics of changing risk. In Emerging Pests and Vector-borne Diseases in Europe (ed. Takken, W. and Knols, B. G. J.), pp. 187-206. Wageningen Academic Publishers, Wageningen.

Randolph, S. E., Gern, L. and Nuttall, P. A. (1996). Co-feeding ticks: epidemiological significance for tick-borne pathogen transmission. Parasitology Today 12, 472-479.

Randolph, S. E., Miklisova, D., Lysy, J., Rogers, D. J. and Labuda, M. (1999). Incidence from coincidence: patterns of tick infestations on rodents facilitate transmission of tick-borne encephalitis virus. Parasitology 118, 177-186.

Rechav, Y. and Nuttall, P. A. (2000). The effect of male ticks on the feeding performance of immature stages of Rhipicephalus sanguineus and Amblyomma americanum (Acari: Ixodidae). Experimental and Applied Acarology 24, 569-578.

Ribeiro, J. M. C. (1987). Ixodes dammini - salivary anti-complement activity. Experimental Parasitology 64, 347-353.

Ribeiro, J. M. C. (1995). How ticks make a living. Parasitology Today 11, 91-93.

Ribeiro, J. M. C. and Spielman, A. (1986). Ixodes dammini - salivary anaphylatoxin inactivating activity. Experimental Parasitology 62, 292-297. Ribeiro, J. M. C., Weis, J. J. and Telford, S. R. (1990). Saliva of the tick Ixodes dammini inhibits neutrophil function. Experimental Parasitology 70, 382-388.

Richter, D., Allgower, R. and Matuschka, F. R. (2002). Co-feeding transmission and its contribution to the perpetuation of the Lyme disease spirochete Borrelia afzelii. Emerging Infectious Diseases 8, 1421-1425.

Richter, D., Allgower, R. and Matuschka, F. R. (2003). Co-feeding transmission and its contribution to the perpetuation of the Lyme disease spirochete Borrelia afzelii. Emerging Infectious Diseases 9, 895-896.

Richter, D., Debski, A., Hubalek, Z. and Matuschka, F. R. (2012). Absence of Lyme disease spirochetes in larval Ixodes ricinus ticks. VectorBorne and Zoonotic Diseases 12, 21-27.

Rollend, L., Fish, D. and Childs, J. E. (2013). Transovarial transmission of Borrelia spirochetes by Ixodes scapularis: a summary of the literature and recent observations. Ticks and Tick-borne Diseases 4, 46-51.

Rudolf, I., Hubalek, Z. and Hubálek, Z. (2003). Effect of the salivary gland and midgut extracts from Ixodes ricinus and Dermacentor reticulatus (Acari: Ixodidae) on the growth of Borrelia garinii in vitro. Folia Parasitologica 50, 159-160.

Rudolf, I., Sikutova, S., Kopecky, J. and Hubalek, Z. (2010). Salivary gland extract from engorged Ixodes ricinus (Acari: Ixodidae) stimulates in vitro growth of Borrelia burgdorferi sensu lato. Fournal of Basic Microbiology 50, 294-298

Sato, Y. and Nakao, M. (1997). Transmission of the Lyme disease spirochete, Borrelia garinii, between infected and uninfected immature Ixodes persulcatus during cofeeding on mice. Fournal of Parasitology 83, 547-550.

Scheckelhoff, M., Telford, S., Wesley, M. and Hu, L. (2007). Borrelia burgdorferi intercepts host hormonal signals to regulate expression of outer surface protein A. Proceedings of the National Academy of Sciences of the United States of America 104, 7247-7252.

Schmidt, K. A., Ostfeld, R. S. and Schauber, E. M. (1999). Infestation of Peromyscus leucopus and Tamias striatus by Ixodes scapularis (Acari: Ixodidae) in relation to the abundance of hosts and parasites. Fournal of Medical Entomology 36, 749-757.

Scott, M. C., Harmon, J. R., Tsao, J. I., Jones, C. J. and Hickling, G. J. (2012). Reverse line blot probe design and polymerase chain reaction optimization for bloodmeal analysis of ticks from the eastern United States. Fournal of Medical Entomology 49, 697-709.

Shaw, M., Keesing, F., McGrail, R. and Ostfeld, R. (2003). Factors influencing the distribution of larval blacklegged ticks on rodent hosts. The American Fournal of Tropical Medicine and Hygiene 68, 447-452. Shih, C. M., Spielman, A., Pollack, R. J. and Telford, S. R. (1992). Delayed dissemination of Lyme disease spirochetes from the site of deposition in the skin of mice. The Gournal of infectious diseases 166, 827-831. Shih, C. M., Chao, L.L. and Yu, C.P. (2002). Chemotactic migration of the Lyme disease spirochete (Borrelia burgdorferi) to salivary gland extracts of vector ticks. American fournal of Tropical Medicine and Hygiene 66, 616-621.

Sonenshine, D. E. (2004). Pheromones and other semiochemicals of ticks and their use in tick control. Parasitology 129(Suppl), S405-425.

Stearns, S. C. (1992). The Evolution of Life-Histories. Oxford University Press, Oxford

Steele, G. M. and Randolph, S. E. (1985). An experimental evaluation of conventional control measures against the sheep tick, Ixodes ricinus (L.) (Acari, Ixodidae). I. A unimodal seasonal activity pattern. Bulletin of Entomological Research 75, 489-499. 
Swanson, K. I. and Norris, D. E. (2008). Presence of multiple variants of Borrelia burgdorferi in the natural reservoir Peromyscus leucopus throughout a transmission season. Vector-Borne and Zoonotic Diseases 8, 397-405.

Taragel'ová, V., Koci, J., Hanincova, K., Kurtenbach, K., Derdakova, M., Ogden, N.H., Hanincová, K., Derdáková, M. Literák, I., Kocianová, E. and Labuda, M. (2008). Blackbirds and song thrushes constitute a key reservoir of Borrelia garinii, the causative agent of borreliosis in Central Europe. Applied and Environmental Microbiology $\mathbf{7 4}$ 1289-1293.

Telford, S. R., Mather, T. N., Moore, S. I., Wilson, M. L. and Spielman, A. (1988). Incompetence of deer as reservoirs of the Lymedisease spirochete. American Fournal of Tropical Medicine and Hygiene 39, 105-109.

Tonetti, N. and Gern, L. (2011). Dynamic of host-tick-host transmission of Borrelia afzelii osp C groups. In Seventh Ticks and Tick-borne Pathogens International Conference, Zaragoza, Spain.

Tsao, J. (2009). Reviewing molecular adaptations of Lyme borreliosis spirochetes in the context of reproductive fitness in natural transmission cycles. Veterinary Research (Paris) 40, 36.

Wang, G., Ojaimi, C., Iyer, R., Saksenberg, V., McClain, S. A., Wormser, G. P. and Schwartz, I. (2001a). Impact of genotypic variation of Borrelia burgdorferi sensu stricto on kinetics of dissemination and severity of disease in $\mathrm{C} 3 \mathrm{H} / \mathrm{HeJ}$ mice. Infection and Immunity 69, 4303-4312.

Wang, H., Paesen, G. C., Nuttall, P. A. and Barbour, A. G. (1998). Male ticks help their mates to feed. Nature 391, 753-754.

Wang, H., Hails, R. S., Cui, W. W. and Nuttall, P. A. (2001b) Feeding aggregation of the tick Rhipicephalus appendiculatus (Ixodidae) benefits and costs in the contest with host responses. Parasitology 123(Pt 5), 447-453.

Wang, I. N., Dykhuizen, D. E., Qiu, W., Dunn, J. J., Bosler, E. M. and Luft, B. J. (1999). Genetic diversity of $\operatorname{cs} p C$ in a local population of Borrelia burgdorferi sensu stricto. Genetics 151, 15-30.

Woolhouse, M. E., Dye, C., Smith, T., Etard, J. F., Charlwood, J. D., Garnett, G. P., Hagan, P., Hii, J. L., Ndhlovu, P. D., Quinnell, R. J., Watts, C. H., Chandiwana, S. K. and Anderson, R. M. (1997). Heterogeneities in the transmission of infectious agents: implications for the design of control programs. Proceedings of the National Academy of Sciences of the United States of America 94, 338-342.

Zeidner, N. S., Gern, L., Piesman, J., Schneider, B.S. and Nuncio, M.S. (2002). Coinoculation of Borrelia spp. with tick salivary gland lysate enhances spirochete load in mice and is tick species-specific. The Fournal of Parasitology 88, 1276-1278. 